A Nordic open access journal in Theology, Philosophy and Culture

Published by NLA University College - in partnership with Johannelund School of Theology

Available at www.theofilos.no

\title{
Exploring Genesis 1-3 as a True Worldview Story: \\ Reading alongside C. S. Lewis, Francis A. Schaeffer, and C. John Collins
}

\author{
Lars Dahle \\ Associate Professor in Systematic Theology \\ NLA University College, Kristiansand, Norway \\ lars.dable@nla.no \\ Bjørn Hinderaker \\ Assistant Professor in Communication and Worldviews \\ NLA University College, Kristiansand, Norway \\ bjorn.hinderaker@nla.no
}

I still think that a 'broadly Lewisian' and 'broadly Schaefferian' tack when it comes to

Genesis will provide us with the intellectually and morally robust tools we need for bringing the message of Genesis to each culture.

$$
\text { C. John ("Jack") Collins" }
$$

As co-editors of this Theofilos Supplement issue, we are delighted that the issue contains such a wealth of valuable contributions. As theologians and apologists, we find Jack Collins' approach promising, not the least because he draws on key insights from the two influential 20th century apologists C. S. Lewis and Francis A. Schaeffer ${ }^{1}$ in his exposition and application of Genesis $1-3$ as a true worldview story.

We have a threefold intention with this article. First, to introduce some key contributions from Schaeffer, Lewis and Collins, largely in their own words. Secondly, to indicate why we find their contributions attractive and worthy of further explorations. Thirdly, in view of these contributions, to offer some brief, final reflections on how to understand Genesis 1-3 in worldview terms and how to integrate and apply this worldview story in our apologetics.

\section{S. Lewis on grasping a story and the Story}

\section{Approaching any story with Lewis}

As a Genesis specialist with a keen interest in issues of faith and science, Jack Collins was well suited to serve as Research Fellow at the Creation Project at the Carl F. Henry Center for Theological Understanding. This project is a major initiative "designed to nurture evangelical

\footnotetext{
* Lewis and Schaeffer were two of the most influential Christian apologists in the 20th Century in their own right. We have a special affinity to these two apologists in our academic Communication and Worldviews programme (in Norwegian: "kommunikasjon og livssyn"). This is due both to their foundational theological orientation, their significant - and quite different - contributions to Christian apologetics, and their deep understanding of the importance of worldviews in Christian apologetics.
} 
engagement with the doctrine of creation in all of its historical, theological, and scientific complexity."2 Collins' research resulted in the publication of a fascinating monograph entitled Reading Genesis Well: Navigating History, Poetry, Science, and Truth in Genesis 1-11 (2018)

In an interesting interview with Bible Gateway, Collins explains how he discovered his starting point in this study in C. S. Lewis' professional writings on English language and literature:

Lewis' professional writings display an intuitive grasp of disciplines that are nowadays held separate, such as rhetoric, literary interpretation, and linguistics - and these disciplines can, if used wisely, help us to make our reading more careful. In Lewis' intuitions we see the benefits of not separating what God has joined together, and that's what I've put to work here...

Lewis began one of his books this way: "The first qualification for judging any piece of workmanship from a corkscrew to a cathedral is to know what it is - what it was intended to do and how it is meant to be used." 3

Straightaway, Lewis has drawn our attention to three aspects of a work of literary craftsmanship:

1) What it is: issues of things like "genre," style, and register; What is the relation of literary form and the content?

2) What it was intended to do: What effect does the work aim to produce in its users?

3) How it is meant to be used: What kind of users are envisioned by the work, what knowledge and beliefs do they share with the author, what kind of social setting is the normal locus of use? 4

As we will see below, Collins shows how these three foundational questions may be highly significant for a deeper and more balanced reading of the early chapters of Genesis.

\section{Approaching the biblical Story with Lewis}

We may connect these literary insights from Lewis to his well-known emphasis on the deeper theological significance of 'mythical' stories. As Alister McGrath points out, this was an insight that Lewis gained from his friend J. R. R. Tolkien:

[A conversation with Tolkien in
1931] helped Lewis realize that
myths in the technical literary sense
of the term - were 'profound and
suggestive of meanings' that lay be-
yond his grasp, so that he was
unable to state in plain language
'what it meant'.

For Lewis, a myth is a story that evokes awe, enchantment, and inspiration, and conveys or embodies an imaginative expression of the deepest meanings of life. Lewis came to see that the story of Christ was a "true myth" - that is to say, a myth that functions in the same manner as other myths yet really happened. Christianity possessed the literary form of a myth, with the critical difference that it was true. The story of Christ is thus to be understood as 'God's myth', whereas the great pagan narratives are 'men's myths'. ${ }^{5}$

McGrath continues by clarifying how Lewis uses the term 'myth':

Many, particularly within the American evangelical community, misunderstand Lewis at this point, believing that his use of the term 'myth' implies that Christianity is fictional or false. As recent scholarship has made clear, however, a "myth" is ultimately a worldview that is presented in the form of a narrative. ${ }^{6}$

This biblical story makes sense of our glo- 
bal story as a common humanity. In Lewis' own words: "Christianity, going on from [the Hebrew Bible], makes world history in its entirety a single, transcendentally significant, story with a well-defined plot pivoted on Creation, Fall, Redemption, and Judgement."7 Thus, according to Lewis, the Bible provides us with a coherent worldview story from creation and fall, towards Christ and the ultimate consummation.

\section{Appreciating an imaginative retelling of the Story with Lewis}

We will now highlight two examples of how Lewis uses a 'mythical' retelling of the biblical Story, as his creative way of communicating rich biblical truth.

The first one is the imaginative re-telling of the creation story in the famous Narnia story The Magician's Nephew:

In the darkness something was happening at last. A voice had begun to sing. It was very far away and Digory found it hard to decide from what direction it was coming. Sometimes it seemed to come from all directions at once. Sometimes he almost thought it was coming out of the earth beneath them. Its lower notes were deep enough to be the voice of the earth herself. There were no words. There was hardly even a tune. But it was, beyond comparison, the most beautiful noise he had ever heard. It was so beautiful he could hardly bear it. The horse seemed to like it too: he gave the sort of whinny a horse would give if, after years of being a cab-horse, it found itself back in the old field where it had played as a foal, and saw someone whom it remembered and loved coming across the field to bring it a lump of sugar. "Gawd!" said the Cabby. "Ain't it lovely?" Then two wonders happened at the same mo- ment. One was that the voice was suddenly joined by other voices; more voices than you could possibly count. They were in harmony with it, but far higher up the scale: cold, tingling, silvery voices. The second wonder was that the blackness overhead, all at once, was blazing with stars. They didn't come out gently one by one, as they do on a summer evening. One moment there had been nothing but darkness; next moment a thousand, thousand points of light leaped out - single stars, constellations, and planets, brighter and bigger than any in our world. There were no clouds. The new stars and the new voices began at exactly the same time. If you had seen and heard it, as Digory did, you would have felt quite certain that it was the stars themselves who were singing, and that it was the First Voice, the deep one, which had made them appear and made them sing... 8

... The Lion was pacing to and fro about that empty land and singing his new song. It was softer and more lilting than the song by which he had called up the stars and the sun; a gentle, rippling music. And as he walked and sang the valley grew green with grass. It spread out from the Lion like a pool. It ran up the sides of the little hills like a wave. In a few minutes it was creeping up the lower slopes of the distant mountains, making that young world every moment softer. The light wind could now be heard ruffling the grass. Soon there were other things besides grass. The higher slopes grew dark with heather. Patches of rougher and more bristling green appeared in the valley. Digory did not know what they were until one began coming up quite close to him. It was a little, spiky thing that grew out dozens of arms and covered these arms with 
green and grew larger at the rate of about an inch every two seconds. There were dozens of these things all round him now. When they were nearly as tall as himself, he saw what they were. "Trees!" he exclaimed." 9

This beautiful, re-imagining of the Genesis 1 story fills us with wonder and joy, if we let it speak to us on a deeper level.

The second example of Lewis' retelling of the Genesis 1-3 story is from Pereland$\mathrm{ra}$, the second book in his science fiction trilogy. It relates how temptation is brought to the planet Perelandra (our Venus), a world with completely innocent inhabitants. It is the mad human scientist, Weston, who is the vehicle for tempting the queen of the planet, Green Lady. He goes to great length to argue that she should disobey the one command from Maleldil (Perelandra's name for God) that they must never stay the night at the Fixed Island. Weston is arguing that Maleldil really intends her to disobey his commands:

'These other commands of His-to love, to sleep, to fill this world with your children-you see for yourself that they are good. And they are the same in all worlds. But the command against living on the Fixed Island is not so. You have already learned that He gave no such command to my world. And you cannot see where the goodness of it is. No wonder. If it were really good, must He not have commanded it to all worlds alike? For how could Maleldil not command what was good? There is no good in it. Maleldil Himself is showing you that, this moment, through your own reason. It is mere command. It is forbidding for the mere sake of forbidding.'

'But why ...?'
'In order that you may break it. What other reason can there be? It is not good. It is not the same for other worlds. It stands between you and all settled life, all command of your own days. Is not Maleldil showing you as plainly as $\mathrm{He}$ can that it was set up as a test - as a great wave you have to go over, that you may become really old, really separate from Him.'

'But if this concerns me so deeply, why does He put none of this into my mind? It is all coming from you, Stranger. There is no whisper, even, of the Voice saying Yes to your words.'

'But do you not see that there cannot be? He longs-oh, how greatly He longs-to see His creature become fully itself, to stand up in its own reason and its own courage even against $\mathrm{Him}$. But how can $\mathrm{He}$ tell it to do this? That would spoil all. Whatever it did after that would only be one more step taken with Him. This is the one thing of all the things $\mathrm{He}$ desires in which $\mathrm{He}$ must have no finger. Do you think $\mathrm{He}$ is not weary of seeing nothing but Himself in all that He has made? If that contented Him, why should He create at all? To find the Other - the thing whose will is no longer His - that is Maleldil's desire.' 10

Again, we are struck by Lewis' imaginative retelling of the biblical story. Thus, both examples illustrate that deep truths of the Christian worldview may be communicated powerfully through various forms of imaginative narratives.

\section{Francis A. Schaeffer on approa- ching Genesis and science}

\section{Locating Genesis in Space and Time with Schaeffer \\ Like Jack Collins, we have also been influenced by C. S. Lewis and Francis A.}


Schaeffer. Whereas Collins specifically refers to a key booklet by Schaeffer called No Final Conflict (see below), we would also like to highlight Schaeffer's book on Genesis 1-11 called Genesis in Space and Time.

In this book, the early chapters of Genesis are immediately related to the larger worldview questions:

In some ways [Genesis 1-11] are the most important chapters in the Bible, for they put man in his cosmic setting and show him his peculiar uniqueness. They explain man's wonder and yet his flaw. Without a proper understanding of these chapters we have no answer to the problems of metaphysics, morals, or epistemology, and furthermore the work of Christ becomes one more upper-story 'religious' answer. ${ }^{11}$

Schaffer claims that we should not understand the early chapters of Genesis as unhistorical myths, but as credible stories firmly located in our space and time reality. Therefore, they speak with trustworthiness and relevance to our real world.

\section{Exploring Genesis as an Explanatory Worldview Story with Schaeffer}

Schaeffer was well-known for his worldview approach in apologetics, where he contrasted a biblical worldview with alternative perspectives. This was also the case in Genesis in Space and Time. Here we will quote one of Schaeffer's classical arguments at length. The major thrust of his argumentative approach is that alternative non-Christian worldviews do not have satisfactory answers to the big questions in life:

An impersonal beginning... raises two overwhelming problems which neither the East nor modern man has come anywhere near solving.
First, there is no real explanation for the fact that the external world not only exists but has a specific form. Despite its frequent attempt to reduce the concept of the personal to the area of chemical or psychological conditioning, scientific study demonstrates that the universe has an express form. One can go from particulars to a greater unity, from the lesser laws to more and more general laws or super-laws. In other words, as I look at the Being which is the external universe, it is obviously not just a handful of pebbles thrown out there. What is there has form. If we assert the existence of the impersonal as the beginning of the universe, we simply have no explanation for this kind of situation.

Second, and more important, if we begin with an impersonal universe, there is no explanation of personality. In a very real sense, the question of questions for all generations -- but overwhelmingly so for modern man -- is, "Who am I?" For when I look at the "I" that is me and then look around to those who face me and are also men, one thing is immediately obvious: Man has a "mannishness." You find it wherever you find man -- not only in the men who live today, but in the artifacts of history. The assumption of an impersonal beginning cannot adequately explain the personal beings we see around us; and when men try to explain man on the basis of an original impersonal, man soon disappears.

In short, an impersonal beginning explains neither the form of the universe nor the personality of man. Hence it gives no basis for understanding human relationships, building just societies, or engaging in any kind of cultural effort. It is not just the man in the university who needs to understand these ques- 
tions. The farmer, the peasant, anyone at all who moves and thinks needs to know. That is, as I look and see that something is there, I need to know what to do with it. The impersonal answer at any level and at any place at any time of history does not explain these two basic factors -- the universe and its form, and the "mannishness" of man. And this is so whether it is expressed in the religious terms of pantheism or modern scientific terms.

But the Judeo-Christian tradition begins with the opposite answer. And it is upon this that our whole Western culture has been built. The universe had a personal beginning a personal beginning on the high order of the Trinity. That is, before "in the beginning" the personal was already there. Love and thought and communication existed prior to the creation of the heavens and the earth. ${ }^{12}$

We would like to suggest that this worldview approach continues to be relevant for Christian apologetics, even though it may need to be further developed, as more nuanced, specific, and contextual.

\section{Claiming No Conflict between Genesis and science with Schaeffer}

In the booklet No Final Conflict'13 Schaeffer's concern is with the trustworthiness and authority of the Scriptures over against 'neo-orthodox existentialist' theologies, where the Bible is emptied from propositional content.

The issue is whether the Bible is God's verbalized communication to men giving propositional truth where it touches the cosmos and history, or whether it is only in some sense "revelational" where it touches matters of religion. The early chapters of Genesis relate to this discussion, but ultimately the question is not (and cannot be) confined to them: the whole Bible is involved. ${ }^{14}$

If we try to separate the religious passages in the book of Genesis from those which touch on history and the cosmos, the religious passages are relegated to an upper-story situation. They have been removed from any connection to space-time verification, and that means no historical or scientific study can refute them. But it also follows that no studies can verify them. In short, there is no reason to accept the upper-story religious things either. The upper-story religious things only become a quarry out of which to have our own personal subjective, existential, religious experience. There is no reason, then, to think of the religious things as being other than in one's own head. ${ }^{15}$

Even though Schaeffer has a strong, conservative evangelical view of the Bible, he proposes an approach to Genesis 1-3 with freedoms and limitations.

In terms of "freedoms", Schaeffer lists seven possible interpretations of Genesis $1-3$, while not explicitly supporting any of them: (1) God may have created a "grown up universe". (2) There may have been a time gap between verses 1 and 2, and verses 2 and 3. (3) It is possible that Genesis 1 talk about a "long day". (4) The flood may have affected the geological data. (5) The word "kind" in Gen $1: 11$ is not synonymous with species. (6) There may have been animal death before the Fall. (7) Only the word 'bara' must imply an absolute beginning.

On the other hand, Schaeffer suggests two "limits". The first is that "the word bara insists that the original creation, at the creation of conscious life and the creation of man there was specific discontinuity with what preceded." 16 The second 
is holding that "Adam was historic and was the first man and that Eve was made from Adam." For the latter point he refers to the NT, which means that this question also involves the whole authority of the NT including Paul.

When assessing Schaeffer's approach, Collins summarizes as follows:

He has covered the main options that evangelicals in his day had explored. And surely his instincts are right... At the same time, a great deal of water has gushed on by under the exegetical bridge since his booklet first saw publication in 1975, and thus I would take his list of freedoms as enumerative and suggestive, rather than exhaustive. The limitations strike me as eminently reasonable, and indeed generous. ${ }^{17}$

Thus, this approach seeks to formulate a constructive framework for the discussion on the early chapters of Genesis which allows for different ways of interpreting, while at the same time upholding some fundamental theological commitments.

\section{The Schaeffer Legacy: The L'Abri Statement on Creation and Evolution}

The L'Abri movement has felt the impact of the ongoing discussion on Genesis and science. In 2012, the Board of Trustees felt it necessary to formulate a statement on the issue, where they attempted to formulate the legacy from Schaeffer. The statement bears quoting in full:

\section{Creation/Evolution Summary Statement}

The Creation/Evolution debate can be complex, confusing and all too often controversial. But it has nevertheless been important within L'Abri to speak to the issues invol- ved. L'Abri has in fact produced many lectures and even a few books relevant to the subject. Schaeffer himself frequently addressed the issue in a number of places, not least in his book Genesis in Space and Time. There we find a good summary of the L'Abri approach to this subject.

We note that Schaeffer does not major on attacking Evolution as a scientific system. He does not get into the biology or the fossil records, etc. Rather his focus is on drawing out the central Biblical teaching on origins and contrasting it at critical points with the paradigm that he called 'the impersonal plus time plus chance' and its implications.

His focus is on the key ideas and their consequences rather than their origins in a particular scientific theory - and he never comes across as anti-science. $\mathrm{He}$ is extremely careful to leave room for debate on issues he feels not completely clear in Scripture and yet he never loses focus on the critical importance of defending a 'space-time' Creation. So he allows freedom of opinion on the lengths of the days, on animal death before the Fall, on the extent of the flood - all of which shows him to be remarkably free of his own fundamentalist heritage.

And yet he is crystal clear that there was an historical Adam and Eve, an historical Fall, and multiple moments of creative intervention by God. The enemy for him is not necessarily evolution per se, but rather - an impersonal universe, a chance origin, the absence of the supernatural, the uniformity of natural causes in a closed system, and man as [a] biological machine. What is defended is not so much a detailed pseudoscientific Creationism but rather the critical importance of divine supernatural acti- 
vity, of design and purpose, of the image of God in Man, of human death (including physical death) as a result of God's judgment, and a real historical flow in Genesis.

These continue to be the central affirmations and denials that shape our perspective in L'Abri today. As time moves on, various interpretations of Genesis and different scientific theories will doubtless come and go. Questions about exactly how God has interacted with Creation and to what degree $\mathrm{He}$ has used secondary causes to achieve His purposes will always prove challenging. Consequently, we also want to leave room for new data and fresh perspectives arising in our own moments of history, as these may call us to re-examine our positions. But in the matter of our origins, the theological affirmations and denials listed above will remain the key convictions we will want to stand on.

L'Abri Trustees

November 30th, 201218

This statement follows Schaeffer's key approach in focusing on the major worldview issues, affirming some basic theological commitments, while leaving the discussion open on several other issues.

\section{Reading Genesis 1-3 with Jack Collins - inspired by Lewis and Schaeffer}

As a leading evangelical specialist on Genesis, Collins has contributed many academic and more popular publications on Genesis 1-3. This part of our essay will therefore be highly selective and only indicative. We will focus on the three key literary questions from Lewis and on Schaeffer's freedoms and limitations approach.

\section{Answering the first question from} Lewis: "What it is"

When it comes to identifying the literary characteristics of Genesis 1:1-2:3, Collins uses the term exalted prose narrative. The literary form is narrative, while the style or register of the narrative is exalted prose. This is based on several observations from the text, including the following:

1. The pericope consists of an almost liturgical recounting of God's achievements...

2. We have a highly patterned presentation of the days. ...

3 . The narrative is exceedingly broad in its taxonomies...

4. The name for the heavens, [raqia'], the "expanse," is unusual and probably rhetorically "high" or poetic ...

5. The sun and the moon are given very allusive names ("greater light" and "lesser light"), names that are not normal for the Bible...

6. God takes a rest on his Sabbath (but every faithful person knows that God never gets tired).

7. The events are, in the nature of the case (creation), unique, which supplies a good reason for a unique style. ${ }^{19}$

But granted that Genesis 1:1-2:3 is an exalted prose narrative, what is it all about? Collins has become well-known for his analogical day position: "The creation days are God's workdays, their length is neither specified nor important, and not everything in the account needs to be taken as historically sequential." 20

The analytical overview provided by Bruce Gordon is a succinct summary of this position and approach:

Collins argues that Genesis 1:1 is best interpreted as a summary of God's activity prior to the first day of creation in Genesis 1:3, which 
allows for an unspecified period of time to have passed prior to God's beginning to shape the earth for habitability.

Collins develops his analogical understanding in light of the following considerations: (1) the ongoing nature of the seventh "day" that lacks an evening and a morning (Gen. 2:2); (2) the expansion of the sixth "day" in the second creation account (Gen. 2:5-25); (3) a lexicogrammatical resolution of the problem of the fourth "day" in which - since God here tasks the sun, moon, and stars to govern the day and night (Gen. 1:14-16) - the Hebrew allows God's action to be that of appointing these previously created heavenly bodies (Gen. 1:1) to their function of marking time for sentient life; and (4) the poetic parallelism correlating "days" one to three as a triad with "days" four through six (the literary-framework observation), which indicates that day length and chronology are not primary considerations in the creation account. ${ }^{21}$

As an exalted prose narrative, Genesis 1:1-2:3 should not be interpreted in a literalistic way. As Collins points out in various contributions, a literalistic approach may be found within a wide spectrum of interpretations, including both creationist and theistic evolutionist readings.

Therefore, the passage in Genesis 1 should neither be read as plain history nor as ancient or modern science. This relates to our understanding of 'history' and 'historical':

We appreciate that in ordinary language to say that something is 'historical' is to say that there are actual persons and events for it to refer to and these persons and events really existed. This does not determine the literary form or rhetorical setting in which the referring takes place, however. ... Hence, we must insist that 'history' is not a literary form; it is rather a way of referring to persons and events with a proper moral orientation. ${ }^{22}$

The early chapters of Genesis have a clear historical function in this referential sense, "in the sense that it speaks of real persons and events - even if we have difficulty in locating them precisely in time and space with the tools we currently have"23. We may relate Collin's insightful analysis at this point to Schaeffer's emphasis on the necessity to locate Genesis in real space and time, but without presupposing specific chronology and / or geography.

\section{Answering the second question from Lewis: "What it was intended to do"}

Through his careful analysis of the early chapters of Genesis, Collins uncovers a dual purpose for these chapters:

I take the purpose of Genesis to begin with opposing the origin stories of other ancient peoples by telling of one true God who made heaven and earth, and who dignified humankind with a special nobility, namely, the task of ruling the world wisely and well. 24

... [The] purpose of Genesis $1-11$ is to set the stage for Genesis 12-50, and it does this by clarifying that the God who called Abraham is in fact the one true God for whom all humankind yearns. ${ }^{25}$

Based on these key insights, Collins coined the phrase "the front end of the basic worldview story". It served as the front end of the basic story for ancient Israel, and in the same way it functions as the front end of the big story that defines Christians.

This leads naturally to two questions: 
How can we summarize this story? And what was this 'front end of the basic worldview story' intended to do?

The overall story - of an initially good creation, suitable for habitation and rule by humans exercising wisdom and benevolence; the intrusion of sin into human life, spoiling and disrupting human community; the good Creator steadfastly committed to redeeming his creatures and planning how to bring restoration and eventual fulfillment to them all - this story, I say, rings true. It makes sense of Israel, and it makes sense of Jesus. It enlists you and me to live loyally toward God, to like what he likes, and to embrace our place in the community of his faithful, the community that is a place where together we aspire to be good, and also provide safety for those who aren't very good at being good, and is the key player in this unfolding story. 26

Thus, the worldview story defines and shapes the worldview community.

\section{Answering the third question from Lewis: "How it is meant to be used"}

As the front end of the big story in the Bible, Collins point out that we may identify both a social and a liturgical function of Genesis 1-11:

Its social function is to narrate prehistory and protohistory, with a view to laying the groundwork for the Pentateuch's formation of Israel's identity - to reinforce God's calling: this is who we are, this is where we come from, this is what God intends to do in us and through us; these are the things we are called upon to like and to value. The narration would most often be read aloud in the public sacred gatherings of ancient Israel, and thus also in our Christian services of worship. Its literary form is pre- dominately narrative, with styles that differ from pericope to pericope. Does it aim to tell history? Yes, in the sense that it speaks of real persons and events - even if we have difficulty in locating them precisely in time and space with the tools we currently have. ${ }^{27}$

\section{Upgrading Schaeffer's Freedoms and Limitations Approach}

It is especially in the explorations of Genesis 3 and the relationship between a historical Adam and Eve and science, that Collins has applied Schaeffer's freedoms and limitations approach. He has summarized his fundamental convictions ("limitations") in the following way:

I consider it important to protect three basic affirmations:

1) the human race is one family with a unified origin (regardless of the initial population size);

2) humans arose by a process that goes beyond the impersonal;

and

3) sin is an alien intruder into God's good creation and entered into human experience at some point in the headwaters of human history.

I say, then, that we can preserve the Big Story so long as we maintain the solidarity of the human race in Adam - both his contemporaries and those who came after him. This story has the virtues of being robust in that it can make room for scientific exploration, critical in that it guards our good sense against erroneous views, and sense giving in that it actually addresses our condition and enables us to live faithfully. 28

Thus, Collins proposes that Adam may be described as the "federal head" of humankind, uniting humans in our identity as both image bearers and rebels. 


\section{Brief, final reflections on \\ Genesis $1-3$ as a True Worldview Story}

\section{Applying James Sire's Worldview Definition to Genesis 1-3}

The understanding of Genesis 1-3 as a biblical worldview story, may be illuminated further by James W. Sire's definition of worldviews: ${ }^{29}$

A worldview is a commitment, a fundamental orientation of the heart, that can be expressed as a story or in a set of presuppositions (assumptions which may be true, partially true or entirely false) which we hold (consciously or subconsciously, consistently or inconsistently) about the basic constitution of reality, and that provides the foundations on which we live and more and have our being. ${ }^{30}$

In relation to Genesis 1-3, we may paraphrase the four central elements of this definition as follows: (1) The basic commitment expressed by the author of these chapters is a personal trust in God as Creator, Sustainer, and Lord. The desired fundamental orientation of the heart is a personal covenant relationship with this one, true God. (2) Genesis 1-3 functions as the front end of a true worldview story, told in exalted prose narrative, and was neither intended as an ordinary history nor as ancient or modern science. (3) Genesis 1-3 has a referential function and claims that the basic constitution of reality is a created universe; thus, rejec- ting both ancient and modern alternative secular and religious worldviews. (4) As a true worldview story, it provides the foundation on which we in the Christian worldview community live and move and have our being.

\section{Relating Genesis 1-3 to Paul's Apologetic Argument in Athens}

We suggest that even though this worldview approach is a modern idea conceptually, it corresponds to a large extent to key biblical models. In fact, we find that the apologetic thrust of Genesis 1-3 as a true worldview story is parallel to the initial stages in Paul's apologetic speech to the Areopagos Council in Athens (Acts 17:22-31). Paul's argumentative approach in that context, when faced with Stoicism, Epicureanism, and polytheism, was a move from natural theology through ultimate authority to the Resurrection.

The first two stages in Paul's argument was (i) that a Judeo-Christian natural theology provides the most adequate view of God, the universe and humanity in comparison with other worldviews, and (i) that the Creator and Sustainer, as the Author of life, has absolute and legitimate authority over life. This is also - in broad terms - the overall argumentative move in Genesis 1-3, over against alternative worldview stories. ${ }^{31}$ In conclusion, we suggest that a careful reading of Gen 1-3 as a true worldview story is appropriate both exegetically, theologically, and apologetically. 


\section{Notes}

1 C. John Collins, "Freedoms and limitations: C.S. Lewis and Francis Schaeffer as a Tag Team" [re-published in this issue], p. 169

2 See further https://henrycenter.tiu.edu/section/creation-project/.

3 C. S. Lewis, A Preface to Paradise Lost (Oxford: Oxford University Press, 1942), 1.

4 Jonathan Petersen, "How to interpret the Book of Genesis: An Interview with C. John Collins", BibleGateway Blog February 21, 2019) https://www.biblegateway.com/blog/2019/02/how-to-interpret-thebook-of-genesis-an-interview-with-c-john-collins/

5 Alister E. McGrath, Narrative Apologetics: Sharing the Relevance, Joy, and Wonder of the Christian Faith (Grand Rapids, MI: Baker Books, 2019), p 31.

${ }^{6}$ McGrath 2019, pp. 31-32

7 C.S. Lewis, The Discarded Image: An Introduction to Medieval and Renaissance Literature (Cambridge: Cambridge University Press, p. 174.

8 C. S. Lewis, The Magician's Nephew (New York: Macmillan, 1966), pp. 69-70.

${ }^{9}$ Lewis 1966, p. 73.

10 C.S. Lewis, Perelandra, (New York: Harper Collins, 2011), pp. 142-143.

11 Francis A. Schaeffer, Genesis in Space and Time (Madison, WI: InterVarsity Press, 1972) p. 9.

12 Schaeffer 1972, p. 21.

13 Francis A. Schaeffer, No Final Conflict. The Bible Without Error in All That it Affirms (Downers Grove,

IL: Inter-Varsity Press, 1975)

14 Schaeffer 1975 , p. 8.

15 Schaeffer 1975, p. 14.

16 Schaeffer 1975 , p. 33.

17 Collins p. 168 (in this issue).

18 www.labri.org/statements/The-LAbri-Statements.pdf

19 C. John Collins, Reading Genesis Well: Navigating History, Poetry, Science, and Truth in Genesis 1-11

(Grand Rapids, MI: Zondervan, 2018), pp. 155-156.

20 C. John Collins, Genesis 1-4. A Linguistic, Literary, and Theological Commentary (Phillipsburg, NJ: P\&R Publishing, 2006), p. 124.

21 Bruce L. Gordon, "C. John Collins", in Paul Copan et al (eds) Dictionary of Christianity and Science (Grand Rapids, MI: Zondervan, 2017), pp. 98-99.

22 Collins 2018, p. 141.

23 C. John Collins, “RIP, Genre: The Idea Has Run Its Course”, Sapientia, April 4, 2017.

https://henrycenter.tiu.edu/2017/04/genre-has-run-its-course-let-the-word-retire-in-peace

24 Collins 2018, p. 137.

25 Collins 2018, p. 138.

26 Collins 2017 in Sapientia.

27 Collins 2017.in Sapientia.

28 C. John Collins, “Adam as Federal Head”, In: Stanley P. Rosenberg (ed.) Finding Ourselves After Darwin (Grand Rapids, MI: Baker Academic, 2018), p. 4012 [Kindle loc.].

29 See Bjørn Hinderaker, "James W. Sire (1933-2018): Unlikely Academic and Humble Apologist”, Theofilos; 2018 Vol. 10 (1) pp. 78-87; Margunn Serigstad Dahle and Bjørn Hinderaker: "Livssynsteori som perspektiv ved NLA Mediehøgskolen Gimlekollen"; in: Hagesæther, Gunhild et al (eds.) NLA Høgskolen: Fagutvikling og sjølvforståing på kristen grunn (Oslo: Cappelen Damm Akademisk / NOASP, 2020), pp. 147-185. 30 James W. Sire, The Universe Next Door: A Basic Worldview Catalogue (Downers Grove, Ill.: InterVarsity Press, 2004; $4^{\text {th }}$ ed.), p 17.

31 See Lars Dahle, "Truth, Christian Mission and Apologetics: A Response and A Proposal", Norwegian Journal of Missiology 2013, vol. 67 (1), pp. 21-38. Available online at https://journals.mf.no/ntm/article/view/4285/3602. 